\title{
Dietary cation-anion difference and day length have an effect on milk calcium content and bone accretion of dairy cows
}

\author{
A. Boudon, ${ }^{*} \dagger^{1}$ M. Johan, ${ }^{*} \dagger$ A. Narcy, $\ddagger$ M. Boutinaud, ${ }^{*} \dagger$ P. Lamberton, ${ }^{*} \dagger$ and C. Hurtaud ${ }^{*} \dagger$ \\ *INRA, UMR 1348 PEGASE (Physiologie Environnement et Génétique pour l'Animal et le Système d'Elevage), F-35590 Saint-Gilles, France \\ †Agrocampus Ouest, UMR 1348 PEGASE, F-35000 Rennes, France \\ †INRA, UR83 Recherches Avicoles, F-37380, Nouzilly, France
}

\section{ABSTRACT}

Milk and dairy products are an important source of Ca for humans. Recent studies have shown fluctuations in cow milk Ca content during the year in France, with high values in winter and with corn silage diets, and a decrease during May and June and with grass diets. The aim of this study was to identify the reasons for this seasonal decrease in milk Ca content by testing the effect of 2 levels of dietary cation-anion differences (DCAD; $0 \mathrm{mEq} / \mathrm{kg}$ of dry matter for DCAD 0 and $400 \mathrm{mEq} / \mathrm{kg}$ for DCAD 400) and 2 day lengths (8 h of light/d for short days: SD; and $16 \mathrm{~h} / \mathrm{d}$ for long days: LD) on the Ca balances of dairy cows. The DCAD treatments were designed to mimic diets based either on corn silage or on herbage. The cows were only illuminated by solarium lights providing UVA and UVB. The trial was conducted according to 2 simultaneous replicates of a $4 \times 4$ Latin square design using 8 dairy cows averaging $103 \pm 44 \mathrm{~d}$ in milk with 4 periods of 14 d. Data were analyzed by ANOVA with a model including treatment, cow, and period effects. No significant interaction was found between day length and DCAD treatments. With DCAD 400 compared with DCAD 0 , blood $\mathrm{pH}$ increased and plasma ionized $\mathrm{Ca}$ content decreased, whereas the plasma total Ca content did not differ between treatments. Milk Ca content, however, increased with DCAD 400 compared with DCAD 0, in relation to a decrease in the amount of Ca excreted in urine. The DCAD had no significant effect on protein and casein contents and DCAD 400 tended to decrease milk yield. This illustrates that the udder did not decrease Ca uptake from the blood at high DCAD even though DCAD 400 decreased the mammary availability of Ca by decreasing the proportion of blood ionized Ca. Milk $\mathrm{Ca}$ and casein contents were significantly lower

Received April 2, 2015.

Accepted October 23, 2015

${ }^{1}$ Corresponding author: anne.boudon@rennes.inra.fr with LD compared with SD, whereas day length had no effect on milk yield after $14 \mathrm{~d}$ of treatment. Bone accretion of cows increased when the Ca content of milk increased (i.e., with DCAD 400 compared with DCAD 0 and with SD compared with LD). This work suggests that long and sunny days could explain part of the seasonal decrease in milk Ca content in summer and refutes the hypothesis that low milk $\mathrm{Ca}$ contents at grazing could be due to the high DCAD of herbage. Key words: dairy cow, milk composition, mineral metabolism, calcium

\section{INTRODUCTION}

Milk and dairy products in westernized diets represent an optimum source of $\mathrm{Ca}$ and of other limiting nutrients such as $\mathrm{K}$ and $\mathrm{Mg}$ involved in bone health (Caroli et al., 2011). In particular, Ca intake positively affects bone mass, ensuring adequate bone development in childhood and youth (Caroli et al., 2011). Milk Ca is also an important determinant of milk coagulation and cheese-making abilities (Malacarne et al., 2014). Recent studies in France have shown a fluctuation in cow milk total Ca content during the year with a decrease of 100 to $200 \mathrm{mg} / \mathrm{kg}$ during May and June and with grass diets compared with diets based on corn silage (Hurtaud et al., 2011, 2014). In these studies, milk Ca contents could be low enough to impair rennet coagulation ability of milk (Malacarne et al., 2014). It has been established that a genetic variation of milk Ca content exists (van Hulzen et al., 2009) and that milk Ca content is the lowest in mid-lactation (Guéguen and Journet, 1961; van Hulzen et al., 2009). The results obtained by Hurtaud et al. (2011, 2014) suggest that the decrease in milk $\mathrm{Ca}$ content during spring could also be related to other environmental factors such as cow diet and day length. After May, cow diets are based on grazing rather than corn silage in most French dairy systems and day length is perceptibly higher with an increased probability of sunny days compared with the preceding months. A question is if and how these 
changes in environmental conditions could be related to the spring decrease in milk Ca content.

Herbage is a highly cationic forage compared with corn silage, leading to high DCAD when diet is based on this forage (Roche et al., 2000; Apper-Bossard et al., 2006). It cannot be excluded that the high DCAD of herbage-based diet is responsible for the low milk Ca content on these diets. Plasma Ca can be either ionized, which is the biologically active form, or protein-bound. It has been shown that higher DCAD are associated with a lower proportion of plasma ionized Ca (Wang and Beede, 1992; Charbonneau et al., 2006), representing the form preferentially absorbed by the mammary gland. According to Moore (1970), high DCAD can increase blood $\mathrm{pH}$, leading to a higher rate of Ca binding to serum proteins, likely due to a competition between $\mathrm{H}^{+}$and ionized $\mathrm{Ca}$ for binding sites. To our knowledge, the direct effect of DCAD on milk Ca contents has never been observed.

The data of Hurtaud et al. (2011, 2014) also suggested a strong correlation between day length and milk Ca content for a given breed, but this effect could not be fully dissociated from lactation stage. It can be hypothesized that day length could affect Ca metabolism either by UV-stimulated vitamin D synthesis at the skin level or by a photoperiodic effect in relation to melatonin secretion by the pineal gland (Dahl et al., 2000; Hymøller and Jensen, 2010). 1,25OH vitamin D is known to increase Ca intestinal absorption and to favor, with parathyroid hormone, bone resorption and Ca renal tubular reabsorption (Horst et al., 1994). Vitamin D may also play a role in initiating bone remodeling and modeling systems required for repairing bone (Jones et al., 1998; van Driel et al., 2006). However, the link between these effects and the amount of $\mathrm{Ca}$ available for milk synthesis remains to be elucidated. On the other hand, melatonin has been shown to be involved in bone turnover, increasing bone accretion in rodents (Ladizesky et al., 2006) and in sheep (Egermann et al., 2011). Lower circulating melatonin levels and long days have also been shown to increase milk yield in dairy cows (Dahl and Petitclerc, 2003). To our knowledge, however, the effect of melatonin and photoperiod on body flows of $\mathrm{Ca}$ and $\mathrm{Ca}$ balance and milk Ca content in cows remains to be characterized.

Our experiment aimed to explain the declining milk Ca content observed during spring. Our hypotheses were that (1) grazing could be a reason for this decrease because high DCAD of herbage could lead to a decrease in ionized Ca plasma content when cows are grazing, and (2) long days could also interfere with cow Ca metabolism. The aim of this study was thus to test the effect of 2 levels of DCAD calculated to simulate diets based either on corn silage or on herbage, and 2 day lengths, simulated with solarium lights providing UVA and UVB, on the Ca balances of dairy cows.

\section{MATERIALS AND METHODS}

\section{Animals and Experimental Design}

Four treatments, consisting of a factorial arrangement of 2 dietary cation-anion differences $(0 \mathrm{mEq} / \mathrm{kg}$ of DM for DCAD 0 and $400 \mathrm{mEq} / \mathrm{kg}$ of DM for DCAD 400) and 2 day lengths (short days, SD, day length of $8 \mathrm{~h}$ vs. long days, $\mathbf{L D}$, day length of $16 \mathrm{~h} / \mathrm{d}$ ) were compared on 8 lactating multiparous Holstein cows (103 \pm 44 DIM; $31.5 \pm 5.7 \mathrm{~kg} / \mathrm{d}$ milk yield; $677 \pm 57.6 \mathrm{~kg}$ of BW) over 4 periods of $14 \mathrm{~d}$ according to 2 simultaneous replicates of a $4 \times 4$ Latin square design. The DCAD was calculated as the difference between the dietary contents of cations (i.e., $\mathrm{Na}$ and $\mathrm{K}$ ), and anions (i.e., $\mathrm{Cl}$ and $\mathrm{S}$ ), expressed in milliequivalents per kilogram of DM. The 8 cows were kept in 2 chambers, one for each day length, and moved from one period to another to the treatment defined by the Latin square. The succession of treatments in the Latin square was balanced for the carryover effects. In each chamber, all the windows were covered with wood panels during the whole experiment, and special care was taken to switch off the corridor light when opening the doors. Animal feeding, milking, and care were performed under low-intensity red lights. During lightened periods of the day, light was only provided by reflectors containing bulbs with a sun-like radiation spectrum containing UVA and UVB (Ultra-Vitalux, Osram GmbH, München, Germany). For each cow, 4 bulbs were aligned from the head to the tail at a distance of $15 \mathrm{~cm}$ from the skin, the aim being to simulate an amount of radiation of $200 \mathrm{~W} / \mathrm{m}^{2}$. This system was tested before the experiment to ascertain that the cows would not develop any skin burns. Cows were illuminated between 0700 and $1500 \mathrm{~h}$ for SD and between 0500 and $2100 \mathrm{~h}$ for LD. In each chamber, ambient temperature was maintained constant throughout the day at a target temperature of $17^{\circ} \mathrm{C}$ with a thermostatic convective heating system. In the chambers, cows were housed in individual tie stalls (1.4 $\times 2.0 \mathrm{~m}$ ) with individual troughs and individual water bowls with free access to water. The four 14-d periods consisted of $9 \mathrm{~d}$ of adaptation to treatments and $5 \mathrm{~d}$ of measurements. The experiment was conducted at the INRA experimental farm of Mejusseaume (longitude $-1.71^{\circ}$, latitude +48.11 , Brittany, France) from February 6, 2012, to April 6, 2012. Procedures relating to care and use of animals for the experiment were approved by an animal care committee of the French Ministry of Agriculture, in accordance with French regulations (decree-law 2001-464, May 29, 2001). 


\section{Diets and Animal Feeding}

All the cows were fed a TMR of which the basal formula consisted, on a DM basis, of $76.6 \%$ corn silage, $11.6 \%$ energy concentrate, $10.4 \%$ formaldehyde-treated soybean meal, and $1.3 \%$ urea. The energy concentrate consisted of $20 \%$ wheat grain, $20 \%$ barley grain, $20 \%$ corn grain, $20 \%$ beet pulp, $15 \%$ wheat bran, $3 \%$ cane molasses, $1 \%$ sunflower oil, and $1 \% \mathrm{NaCl}$. An amount of $200 \mathrm{~g}$ of sodium bicarbonate was also added daily to each cow's diet. The TMR was formulated to meet the energy and protein requirements of the lactating cows according to INRA (2007) with a ratio of $14 \mathrm{~g}$ of digestible protein in the small intestine per megajoule of net energy. Two mineral supplements were formulated to obtain the 2 levels of DCAD of 0 or $400 \mathrm{mEq} /$ $\mathrm{kg}$ of DM, based on the assumption that intake of the TMR would be $22 \mathrm{~kg}$ of DMI/d. The compositions of both supplements are given in Table 1. An amount of $740 \mathrm{~g} / \mathrm{d}$ of the DCAD 0 mineral supplement and 770 $\mathrm{g} / \mathrm{d}$ of the DCAD 400 mineral supplement was given to the cow according to the treatment. The DCAD 0 and 400 mineral supplements were formulated to provide similar amounts of $\mathrm{Ca}, \mathrm{P}, \mathrm{Mg}$, and $\mathrm{S}$ and to cover the cow's requirement for major minerals $(\mathrm{Ca}, \mathrm{P}, \mathrm{Mg}, \mathrm{Cl}$, $\mathrm{K}, \mathrm{Na}, \mathrm{S})$ and trace elements $(\mathrm{Cu}, \mathrm{Zn}, \mathrm{Mn}, \mathrm{Se}, \mathrm{Co}$, I) according to Meschy (2010). Vitamins A, D, and E were also added to cover the cow's requirements (NRC, 2001). To control mineral supply, no straw or mineral blocks were provided. The diets were fed in 2 equalsized meals per day at 0830 and $1630 \mathrm{~h}$ as a total mixed diet (Table 2), and orts were recorded daily before the a.m. and p.m. feedings. Lactating cows were fed ad libitum and offered quantities were calculated to allow $10 \%$ orts. After the amounts of feed to be distributed were weighed, and before distribution, diets were stored at $4^{\circ} \mathrm{C}$. The lactating cows were milked twice daily at 0645 and $1645 \mathrm{~h}$ in the chambers.

\section{Measurement of Feed Intake and Milk Production and Composition}

Feed Intake. The quantities of offered diets and orts were weighed at each feeding. Before each feeding, each cow's orts were removed and weighed. The DM contents of energy concentrate and soybean meal $\left(80^{\circ} \mathrm{C}, 48 \mathrm{~h}\right)$ were determined weekly, whereas the $\mathrm{DM}$ content of corn silage and orts were determined every day. On each day of the measurement period, before the a.m. and p.m. feedings, 2 representative samples ( $500 \mathrm{~g}$, fresh) of the diet offered were sampled and oven-dried $\left(80^{\circ} \mathrm{C}, 48 \mathrm{~h}\right)$ before being pooled by treatment (DCAD 0 or $400 \mathrm{mEq} / \mathrm{kg}$ ) and period. Orts $(1,000 \mathrm{~g}$, fresh) were also sampled from each cow before the a.m. and
Table 1. Mineral supplement composition ( $\mathrm{g} / \mathrm{kg}$ of ash unless otherwise noted) for DCAD 0 and 400 diets

\begin{tabular}{lcc}
\hline Item & DCAD $0^{1}$ & DCAD $400^{1}$ \\
\hline Offered amount, g/d & 740 & 770 \\
Dibasic calcium phosphate (dihydrate) & 160 & - \\
Disodium phosphate (anhydrous) & - & 122 \\
Calcium carbonate & 400 & 470 \\
Sodium carbonate & - & 290 \\
Magnesium chloride (hexahydrate) & 435 & - \\
Magnesium oxide & - & 100 \\
Sulfur flower & 23 & 25 \\
Copper sulfate (pentahydrate) & 1 & 1 \\
Zinc sulfate (monohydrate) & 3.5 & 3.2 \\
Manganese sulfate (monohydrate) & 4 & 3 \\
Sodium selenite & 0.05 & 0.05 \\
Cobalt carbonate & 0.23 & 0.25 \\
Calcium iodate & 0.04 & 0.05 \\
Vitamin A, $10^{3} \mathrm{IU} / \mathrm{kg}$ & 170 & 170 \\
Vitamin D, $10^{3} \mathrm{IU} / \mathrm{kg}$ & 35 & 35.5 \\
Vitamin E, $10^{3} \mathrm{IU} / \mathrm{kg}$ & 0.5 & 0.5 \\
\hline
\end{tabular}

${ }^{1}$ Mineral supplement provided to obtain a DCAD of 0 or $400 \mathrm{mEq} / \mathrm{kg}$ considering an intake of $22 \mathrm{~kg} / \mathrm{d}$ of the basal TMR.

Table 2. Composition of the TMR for DCAD 0 and 400 diets

\begin{tabular}{|c|c|c|}
\hline Item & DCAD $0^{1}$ & DCAD $400^{1}$ \\
\hline Corn silage, $\%$ of DM & 76.7 & 76.7 \\
\hline Energy concentrate, $\%$ of DM & 11.6 & 11.6 \\
\hline Soybean meal, $\%$ of DM & 10.4 & 10.4 \\
\hline Urea, \% of DM & 1.3 & 1.3 \\
\hline DCAD 0 mineral feed, $\mathrm{g} / \mathrm{d}$ & 740 & \\
\hline DCAD 400 mineral feed, $\mathrm{g} / \mathrm{d}$ & & 769 \\
\hline Sodium bicarbonate, $\mathrm{g} / \mathrm{d}$ & 200 & 200 \\
\hline \multicolumn{3}{|l|}{$\begin{array}{l}\text { Chemical composition expected } \\
\text { for } 21 \mathrm{~kg} \text { of } \mathrm{DMI}^{2}\end{array}$} \\
\hline $\mathrm{DM}, \mathrm{g} / 100 \mathrm{~g}$ & 43.8 & 43.9 \\
\hline $\mathrm{MO}, \mathrm{g} / 100 \mathrm{~g}$ of $\mathrm{DM}$ & 94.8 & 94.8 \\
\hline $\mathrm{CP}, \mathrm{g} / \mathrm{kg}$ of $\mathrm{DM}$ & 157.8 & 158.3 \\
\hline $\mathrm{NDF}, \mathrm{g} / \mathrm{kg}$ of DM & 318.6 & 319.2 \\
\hline $\mathrm{ADF}, \mathrm{g} / \mathrm{kg}$ of $\mathrm{DM}$ & 151.6 & 152.2 \\
\hline $\mathrm{ADL}, \mathrm{g} / \mathrm{kg}$ of DM & 15.6 & 16.1 \\
\hline $\mathrm{Ca}, \mathrm{g} / \mathrm{kg}$ of $\mathrm{DM}$ & 6.94 & 6.36 \\
\hline Absorbable $\mathrm{Ca}, \mathrm{g} / \mathrm{kg}$ of $\mathrm{DM}$ & 3.81 & 3.50 \\
\hline $\mathrm{P}, \mathrm{g} / \mathrm{kg}$ of $\mathrm{DM}$ & 3.83 & 3.25 \\
\hline Absorbable $\mathrm{P}, \mathrm{g} / \mathrm{kg}$ of $\mathrm{DM}$ & 2.49 & 2.11 \\
\hline $\mathrm{Mg}, \mathrm{g} / \mathrm{kg}$ of $\mathrm{DM}$ & 3.13 & 3.18 \\
\hline $\mathrm{K}, \mathrm{g} / \mathrm{kg}$ of $\mathrm{DM}$ & 9.20 & 9.14 \\
\hline $\mathrm{Na}, \mathrm{g} / \mathrm{kg}$ of $\mathrm{DM}$ & 3.96 & 9.49 \\
\hline $\mathrm{Cl}, \mathrm{g} / \mathrm{kg}$ of $\mathrm{DM}$ & 9.45 & 4.70 \\
\hline $\mathrm{S}, \mathrm{g} / \mathrm{kg}$ of $\mathrm{DM}$ & 2.09 & 1.99 \\
\hline \multicolumn{3}{|l|}{ Nutritional value } \\
\hline $\mathrm{NE}_{\mathrm{L}}, \mathrm{MJ} / \mathrm{kg}$ & 7.26 & 7.26 \\
\hline PDIE, ${ }^{3} \mathrm{~g} / \mathrm{kg}$ of DM & 101 & 101 \\
\hline $\mathrm{PDIN}^{4}, \mathrm{~g} / \mathrm{kg}$ of DM & 99 & 99 \\
\hline
\end{tabular}

${ }^{1}$ Mineral supplement provided to obtain a DCAD of 0 or $400 \mathrm{mEq} / \mathrm{kg}$ considering an intake of $22 \mathrm{~kg} / \mathrm{d}$ of the basal TMR.

${ }^{2}$ Composition calculated with results of feed analyses obtained during the experiment.

${ }^{3}$ Digestible protein in the small intestine supplied by microbial protein from rumen-fermented OM (INRA, 2007).

${ }^{4}$ Digestible protein in the small intestine supplied by microbial protein from rumen-degradable protein (INRA, 2007). 
p.m. feedings and oven-dried for DM determination, before being pooled by cow and by period. Feed and ort samples were further analyzed for OM, fiber (NDF, $\mathrm{ADF}$, and $\mathrm{ADL}$ ), $\mathrm{CP}$, and macro-minerals $\mathrm{Ca}, \mathrm{P}, \mathrm{Na}$, $\mathrm{K}, \mathrm{Cl}, \mathrm{Mg}$, and $\mathrm{S}$ and for their pepsin-cellulase digestibility. Water consumption was recorded daily at $0830 \mathrm{~h}$ using water meters associated with each drinking bowl. Feed intake was averaged from d 10 to 13 for statistical analyses.

Milk Production and Composition. Milk production was measured individually at each milking. On d 12 in the evening and d 13 in the morning, approximately $300 \mathrm{~mL}$ of milk per cow and milking was sampled. Samples were frozen at $-20^{\circ} \mathrm{C}$ for further analysis [i.e., NPN, noncasein N (NCN), urea, total and soluble $\mathrm{Ca}$ and $\mathrm{P}, \mathrm{Na}, \mathrm{K}, \mathrm{Cl}$, and $\mathrm{Mg}$ and melatonin contents]. Milk production was averaged from d 11 to 14 for statistical analyses.

\section{Measurement of Calcium and Phosphorus Balances of Cows}

Feces. To determine the fecal excretion of $\mathrm{Ca}, \mathrm{P}$, and $\mathrm{Mg}$, large trays were positioned behind the cows on d 11 at $1100 \mathrm{~h}$. Gross fecal output was weighed and sampled from d 12 at $0900 \mathrm{~h}$ to d 14 at $0900 \mathrm{~h}$. Two representative samples (500 g fresh each) were dried in a forced air oven $\left(80^{\circ} \mathrm{C}, 72 \mathrm{~h}\right)$ to determine $\mathrm{DM}$ content of collected feces and the daily amount of fecal DM excreted. These samples used were pooled by cow and period, and ground through a $0.8-\mathrm{mm}$ screen for further determination of $\mathrm{OM}, \mathrm{Ca}, \mathrm{P}, \mathrm{Na}, \mathrm{K}, \mathrm{Cl}$, and $\mathrm{Mg}$ contents.

Urine. Daily volume of excreted urine was measured from d 11 at $0900 \mathrm{~h}$ to $\mathrm{d} 14$ at $0900 \mathrm{~h}$, by equipping cows with urinary catheters connected by a Tygon tube to a 25-L container, closed with a rubber plug. An amount of $250 \mathrm{~mL}$ of sulfuric acid $(20 \% \mathrm{vol} / \mathrm{vol})$ was added to the container to prevent urine deterioration. The urine was weighed and emptied daily at $0900 \mathrm{~h}$. Each day and for each cow, a sample of $1 \%$ of the daily excreted volume was stored at $-20^{\circ} \mathrm{C}$. At the end of the experiment, these samples were bulked by animal and by period for further $\mathrm{Ca}, \mathrm{P}, \mathrm{Na}, \mathrm{K}, \mathrm{Cl}$, and $\mathrm{Mg}$ content analyses. For $\mathrm{pH}$ measurement, 2 subsamples of urine were collected directly at the end of the catheter on $\mathrm{d}$ 12 at 0700 and $1400 \mathrm{~h}$. Measurement was done immediately after the collection with a portable $\mathrm{pH}$ meter $(\mathrm{pH}$ 340 i, WTW GmbH, Weilheim, Germany).

\section{Blood Sampling}

At the beginning of the experiment, all the cows were fitted with a catheter (length $30 \mathrm{~cm}, 1.02 \mathrm{~mm}$ i.d., 2.16 mm o.d., Fisher Scientific, Strasbourg, France) in the left jugular vein and this catheter was filled with a sterile solution of $9 \% \mathrm{NaCl}$ and $200 \mathrm{IU}$ heparin. On d 13 of each period, blood samples were taken at $0700 \mathrm{~h}$ and $1400 \mathrm{~h}$ using lithium heparinized syringes (Monovette, Sarstedt, Nümbrecht, Germany) and 2-mL blood gas syringes (Monovette). Blood $\mathrm{pH}, \mathrm{CO}_{2}$ partial pressure $\left(\mathbf{p} \mathbf{C O}_{2}\right), \mathrm{O}_{2}$ partial pressure, hemoglobin, bicarbonates, ionized $\mathrm{Ca}, \mathrm{Na}, \mathrm{Cl}$, and $\mathrm{K}$ were analyzed immediately by potentiometry (ABL 80-BASIS SW instrument, Radiometer, Copenhagen, Denmark). Blood gases were measured within 10 min of sampling and were kept on melting ice in the meantime. The other blood samples were centrifuged $\left(12 \mathrm{~min}, 3,000 \times g, 4^{\circ} \mathrm{C}\right)$ to isolate the plasma. Plasma samples for $25-\mathrm{OH}$ vitamin $\mathrm{D}$ analyses were kept at $-20^{\circ} \mathrm{C}$ before subsequent analyses, whereas samples for carboxy-terminal cross-linking telopeptide of type I collagen (CTX) and osteocalcin analyses were kept at $-80^{\circ} \mathrm{C}$.

\section{Chemical Analyses}

Samples of offered diets, orts, and feces were ground with a 3-blade knife mill through a $0.8-\mathrm{mm}$ screen. Ash was determined by calcination at $550{ }^{\circ} \mathrm{C}$ for $5 \mathrm{~h}$ in a muffle furnace. Nitrogen concentration was determined by the Dumas method according to the Association Française de Normalization (AFNOR, 1997) on a Leco apparatus (Leco, St. Joseph, MI). The NDF, ADF, and ADL were analyzed according to Van Soest et al. (1991) on a Fibersac extraction unit (Ankom Technology, Fairport, NY). The $\mathrm{Ca}, \mathrm{Na}, \mathrm{K}$, and $\mathrm{Mg}$ contents of feed, feces, urine, and milk were measured by atomic absorption spectrophotometry (Spectra-AA20 Varian, Les Ulis, France) after mineralization for solid samples $\left(500^{\circ} \mathrm{C}\right.$ for $\left.12 \mathrm{~h}\right)$. Concentrations of $\mathrm{P}$ and $\mathrm{Cl}$ were determined using a KONE PRO multi-parameter analyzer (Thermo Fisher Scientific, Illkirch, France), with a Biolabo kit (kit no. 80005, Biolabo S.A.A., Maizy, France) for chloride determination and by the Allen method for P (Pien, 1969). Milk fat and protein concentrations were determined by a commercial laboratory using mid-infrared analysis (Lillab, Châteaugiron, France). Milk content of total N (Kjeldahl), nonprotein $\mathrm{N}$ (precipitation at $\mathrm{pH} 4.6$ with trichloroacetic acid and filtration), NCN (precipitation at $\mathrm{pH} 4.6$ with $10 \%$ acetic acid and $1 M$ sodium acetate) content, and urea (colorimetric analysis) were determined according to the methods described in Hurtaud et al. (2000). Milk $\mathrm{CP}$ was calculated as total $\mathrm{N} \times 6.38$, milk true protein as $\mathrm{CP}$ minus nonprotein $\mathrm{N}, \mathrm{CN}$ as total $\mathrm{N}$ minus $\mathrm{NCN}$ multiplied by 6.38 , and milk soluble protein as NCN minus nonprotein $\mathrm{N}$ multiplied by 6.38 . Milk citrate was determined by an enzymatic method (Diagnostics Cit- 
ric Acid Kit, Roche Diagnostics, Boulogne-Billancourt, France). Milk total and soluble Ca were analyzed by atomic absorption spectrophotometry on milk and milk ultrafiltrate (Amicon Centrifugal Filter Units, EMD Millipore, Billerica, MA), respectively. Milk total and soluble $\mathrm{P}$ were analyzed by the Allen method. Colloidal $\mathrm{Ca}$ and $\mathrm{P}$ were determined as total $\mathrm{Ca}$ and $\mathrm{P}$ contents minus soluble $\mathrm{P}$ and $\mathrm{Ca}$ contents. Plasma CTX and osteocalcin concentrations were determined by ELISA with a Serum Crosslaps kit from IDS (Paris, France) for CTX and a kit from Quidel (San Diego, CA) for osteocalcin. The $25-\mathrm{OH}$ vitamin D concentrations and milk melatonin were determined by RIA with kits from IDS for 25-OH vitamin D and after extraction with methanol by the method described by (Chesneau et al., 1994) for melatonin.

\section{Statistical Analyses}

Data related were analyzed by SAS PROC GLM (SAS OnlineDoc, version 8, SAS Inc., Cary, NC) using the following model:

$$
\begin{gathered}
Y_{\mathrm{ijkl}}=\mu+\text { DCAD }_{\mathrm{i}}+\text { Day Length }_{\mathrm{j}}+\text { DCAD }_{\mathrm{i}} \\
\times \text { Day Length }_{\mathrm{j}}+\text { Animal }_{\mathrm{k}}+\text { Period }_{\mathrm{l}}+\varepsilon_{\mathrm{ijkl}},
\end{gathered}
$$

where $\mathrm{Y}_{\mathrm{ijkl}}=$ analyzed variable; $\mu=$ overall mean; DCAD $_{\mathrm{i}}=$ effect of DCAD (1 df); Day Length ${ }_{\mathrm{j}}=$ effect of day length (SD vs. LD, 1 df); Animal $_{k}=$ effect of the animal $(7 \mathrm{df}) ;$ Period $_{1}=$ period effect $(3 \mathrm{df})$; DCAD $_{\mathrm{i}} \times$ Day Length $_{\mathrm{j}}=$ interaction between DCAD and day length $(1 \mathrm{df})$. These effects were considered to be significant at $P<0.05$.

\section{RESULTS}

The interaction between DCAD and day length rarely affected the measured parameters; hence, the effects of both DCAD and day length are presented separately.

\section{DCAD Effect}

Target DCAD levels of DCAD 0 and DCAD 400 treatments were met with a DCAD of approximately $-25 \mathrm{mEq} / \mathrm{kg}$ of DM for DCAD 0 and $385 \mathrm{mEq} / \mathrm{kg}$ of DM for DCAD 400 (Table 3). Level of DCAD did not affect total DMI, milk yield or FCM, $\mathrm{NE}_{\mathrm{L}}$, and PDI supplies, but absorbable $\mathrm{Ca}$ and $\mathrm{P}$ supplies were lower with DCAD 400 compared with DCAD 0 (-6.3 and $-7.3 \mathrm{~g} / \mathrm{d}$ for absorbable $\mathrm{Ca}$ and $\mathrm{P}$ supplies, respectively; i.e., 8 and $15 \%$ of averaged absorbable $\mathrm{Ca}$ and $\mathrm{P}$ supplies). Lower dietary absorbable $\mathrm{Ca}$ and $\mathrm{P}$ supplies with DCAD 400 were mainly related to the lower $\mathrm{Ca}$ and $\mathrm{P}$ content of DCAD 400 compared with DCAD 0 diets (Table 2). These differences were not expected from raw materials analyses before mineral feeds processing. Treatment DCAD 400 improved energy balance $(7.5$ MJ of $\left.\mathrm{NE}_{\mathrm{L}}\right)$ and digestible protein balance $(163 \mathrm{~g} / \mathrm{d}$, Table 3), but both absorbable Ca and $\mathrm{P}$ supply excess compared with cow daily requirements were lower with DCAD $400(-5.5 \mathrm{~g} / \mathrm{d}$ and $-6.8 \mathrm{~g} / \mathrm{d}$ for absorbable Ca and $\mathrm{P}$ supply excess, respectively). Absorbable $\mathrm{P}$ supply was slightly lower than cow $\mathrm{P}$ requirements with DCAD 400.

Blood $\mathrm{pH}$, blood bicarbonate content $\left(\mathrm{HCO}_{3}{ }^{-}\right)$, and urine $\mathrm{pH}$ were higher with DCAD 400 compared with DCAD $0(+0.035$ points for blood $\mathrm{pH}, P<0.001$; $+4.65 \mathrm{mmol} / \mathrm{L}$ for $\mathrm{HCO}_{3}{ }^{-}, P<0.001$; and +1.07 points for urine $\mathrm{pH}, P<0.001$, Table 4). Blood $\mathrm{pCO}_{2}$, blood extracellular base excess, and measured strong ion difference $\left(\left[\mathbf{S I D}^{+}\right]\right)$were also higher with DCAD 400 compared with DCAD 0. Blood $\mathrm{pH}, \mathrm{HCO}_{3}{ }^{-}$content, $\left[\mathrm{SID}^{+}\right]$, and extracellular base excess for DCAD 400 were higher than the upper limit of the normal range (Constable, 1999) with values exceeding 7.45 for $\mathrm{pH}$, close to $32 \mathrm{mmol} / \mathrm{L}$ for $\mathrm{HCO}_{3}{ }^{-}$content, higher than 46 $\mathrm{mEq} / \mathrm{L}$ for $\left[\mathrm{SID}^{+}\right]$, and close to $8 \mathrm{mEq} / \mathrm{L}$ for extracellular base excess. Blood ionized Ca content was lower with DCAD 400 compared with DCAD $0(+4.5 \mathrm{mg} / \mathrm{L})$ but neither total blood $\mathrm{Ca}$ content nor blood $\mathrm{P}$ content were affected by DCAD. The DCAD had no effect either on blood vitamin $\mathrm{D}$ content or on milk melatonin content $(P>0.10)$.

Milk total Ca content increased with DCAD 400 compared with DCAD 0 (1,264 vs. $1,232 \mathrm{mg} / \mathrm{kg}, P<$ 0.001 , Table 5). This increase was associated with an increase in milk colloidal Ca content (897 vs. $856 \mathrm{mg} /$ $\mathrm{kg}, P<0.005)$ and milk colloidal Ca-to-CN ratio $(39.9$ vs. $38.0 \mathrm{mg} / \mathrm{g}, P<0.004)$, whereas soluble Ca content was unaffected by DCAD. Level of DCAD had no effect on milk $\mathrm{P}$ and citrate contents $(P>0.10)$. Milk fat content tended to be higher with DCAD 400 compared with DCAD 0 (35.8 vs. $34.2 \mathrm{~g} / \mathrm{kg}, P<0.09$, Table 6$)$ and milk lactose content was higher (46.7 vs. $46.1 \mathrm{~g} /$ $\mathrm{kg}, P<0.05)$. Milk contents of $\mathrm{CP}$, true protein, urea, $\mathrm{CN}$, and soluble protein were unaffected by DCAD $(P$ $>0.10)$.

During the $3 \mathrm{~d}$ of mineral balance measurement, $\mathrm{Ca}$ supply was significantly lower with DCAD 400 (138.7 vs. $151.1 \mathrm{~g} / \mathrm{d}, P<0.001$, Table 7 ). Level of DCAD had no significant effect on the amount of $\mathrm{Ca}$ exported in milk or in feces, but DCAD 400 decreased the amount of Ca exported in urine $(0.66$ vs. $2.18 \mathrm{~g} / \mathrm{d}, P<0.001)$. Level of DCAD had no effect on Ca balance, Ca apparent absorption coefficient and flow, or $\mathrm{Ca}$ absorbed in the digestive tract. The $\mathrm{P}$ supply tended to be lower with DCAD 400 (67.6 vs. $69.9 \mathrm{~g} / \mathrm{d}, P<0.06)$. Level of 
Table 3. Intake, milk yield, and supply and coverage of $\mathrm{NE}_{\mathrm{L}}$, protein, Ca and $\mathrm{P}$ requirements of cows fed low or high $\mathrm{DCAD}$ diets and submitted to short (SD) and long days (LD)

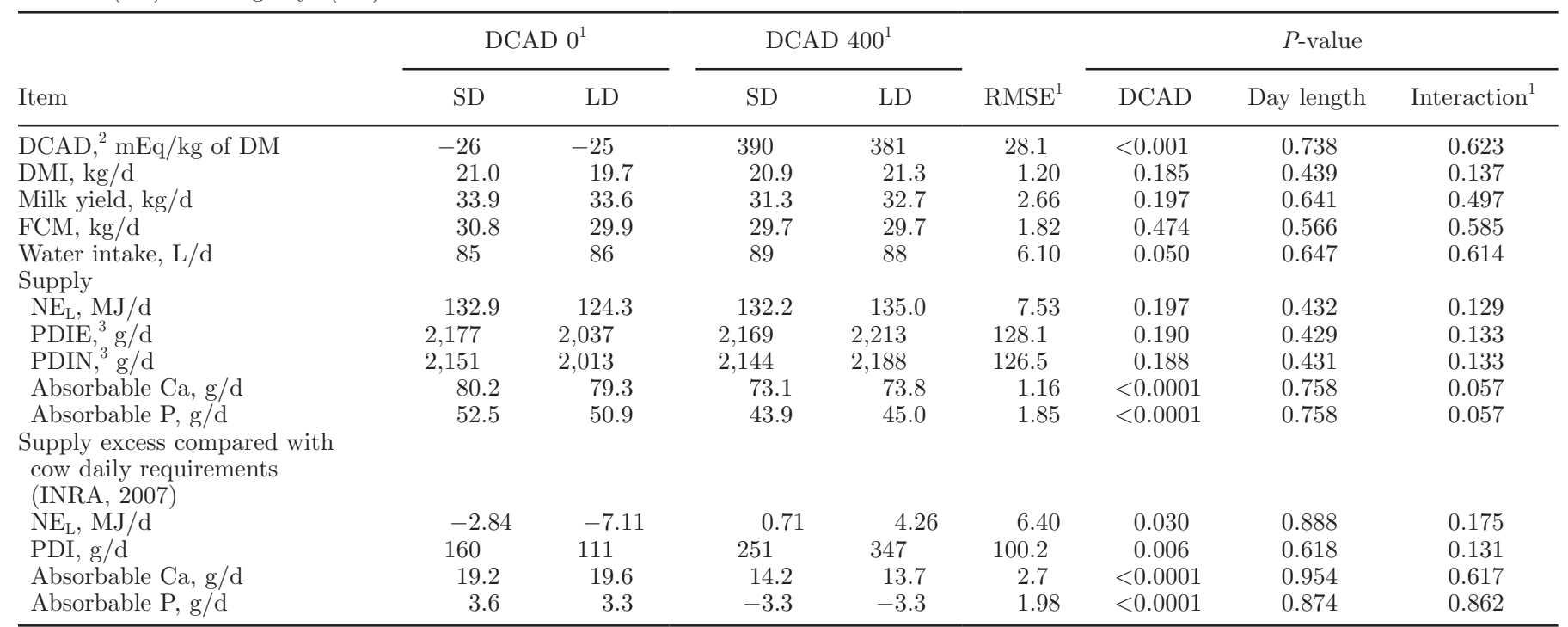

${ }^{1} \mathrm{DCAD} 0$ and DCAD $400=\mathrm{DCAD}$ of 0 or $400 \mathrm{mEq} / \mathrm{kg}$ of DM; RMSE $=$ root mean square prediction error; interaction $=\mathrm{DCAD} \times$ day length interaction.

${ }^{2}$ Dietary cation-anion difference $([\mathrm{Na}]+[\mathrm{K}]-[\mathrm{Cl}]-[\mathrm{S}]$ in milliequivalents per kilogram of dietary DM).

${ }^{3} \mathrm{PDIE}=$ digestible protein in the small intestine supplied by microbial protein from rumen-fermented OM (INRA, 2007); PDIN = digestible protein in the small intestine supplied by microbial protein from rumen-degradable protein (INRA, 2007).

DCAD had no effect on the amount of $\mathrm{P}$ exported in milk or in urine, but DCAD 400 decreased the amount of $\mathrm{P}$ exported in feces $(36.2$ vs. $40.8 \mathrm{~g} / \mathrm{d}, P<0.008)$. Treatment DCAD 400 significantly increased P apparent absorption coefficient (46.8 vs. $41.9, P<0.02)$ and tended to increase $\mathrm{P}$ balance $(0.94$ vs. $-2.13 \mathrm{~g} / \mathrm{d}, P<$ $0.08)$.

Treatment DCAD 400 tended to increase morning plasma osteocalcin concentrations (48.6 vs. $43.0 \mathrm{ng} /$ $\mathrm{mL}, P<0.07)$ and increased evening plasma osteocal-

Table 4. Blood gases, blood Ca, $\mathrm{P}$, and vitamin D (25-OH) contents, milk melatonin contents, and urine pH of cows fed low or high DCAD diets and submitted to short (SD) and long days (LD; when not specified, data were collected from blood sampled in the morning)

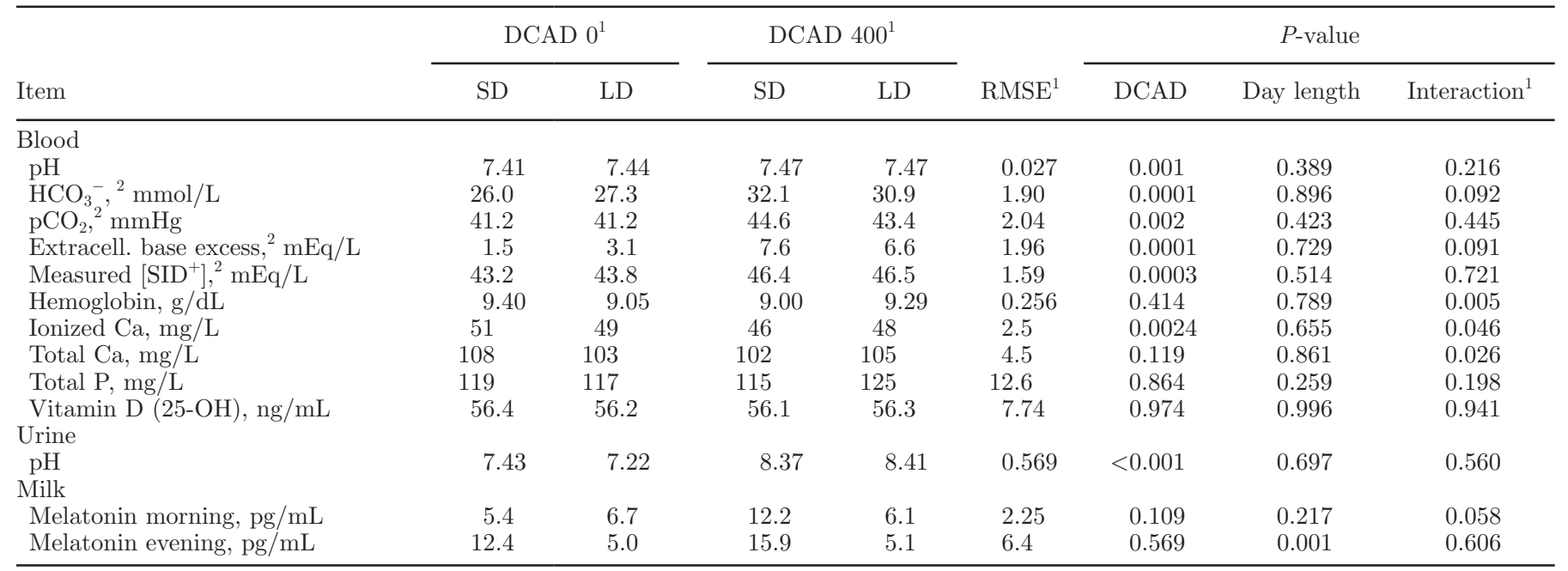

${ }^{1}$ DCAD 0 and DCAD $400=$ dietary cation anion difference of 0 or $400 \mathrm{mEq} / \mathrm{kg}$ of DM; RMSE = root mean square prediction error; interaction $=\mathrm{DCAD} \times$ day length interaction.

${ }^{2} \mathrm{HCO}_{3}{ }^{-}=$real plasma bicarbonates concentration; $\mathrm{pCO}_{2}=$ blood partial pressure of $\mathrm{CO}_{2}$; Extracell. base excess $=$ extracellular base excess of totally oxygenated blood; measured $\left[\mathrm{SID}^{+}\right]=$measured strong ion difference estimated as $\left[\mathrm{Na}^{+}\right]+\left[\mathrm{K}^{+}\right]-\left[\mathrm{Cl}^{-}\right]$, where $\left[\mathrm{Na}^{+}\right],\left[\mathrm{K}^{+}\right]$, and $\left[\mathrm{Cl}^{-}\right]$are the blood concentrations of $\mathrm{Na}, \mathrm{K}$, and $\mathrm{Cl}$ expressed in milliequivalents per liter. 
Table 5. Milk mineral composition of cows fed low or high DCAD diets and submitted to short (SD) and long days (LD)

\begin{tabular}{|c|c|c|c|c|c|c|c|c|}
\hline Item & \multicolumn{2}{|c|}{ DCAD $0^{1}$} & \multicolumn{2}{|c|}{ DCAD $400^{1}$} & $\mathrm{RMSE}^{1}$ & \multicolumn{3}{|c|}{$P$-value } \\
\hline Total Ca content, mg/kg & 1,252 & 1,212 & 1,278 & 1,249 & 30.6 & 0.005 & 0.002 & 0.638 \\
\hline Soluble $\mathrm{Ca}$ content, $\mathrm{mg} / \mathrm{kg}$ & 380 & 368 & 362 & 371 & 25.8 & 0.674 & 0.598 & 0.283 \\
\hline $\begin{array}{l}\text { Ratio of colloidal Ca content to } \\
\text { casein content, } \mathrm{mg} / \mathrm{g}\end{array}$ & 38.1 & 37.8 & 39.9 & 39.9 & 1.63 & 0.004 & 0.764 & 0.794 \\
\hline Colloidal $\mathrm{P}$ content, $\mathrm{mg} / \mathrm{kg}$ & 549 & 541 & 560 & 539 & 38.5 & 0.419 & 0.128 & 0.676 \\
\hline Citrate, $\mathrm{mg} / \mathrm{L}$ & 1,357 & 1,339 & 1,332 & 1,389 & 100 & 0.528 & 0.809 & 0.315 \\
\hline
\end{tabular}

${ }^{1} \mathrm{DCAD} 0$ and DCAD $400=$ dietary cation anion difference of 0 or $400 \mathrm{mEq} / \mathrm{kg}$ of DM; RMSE = root mean square prediction error; interaction $=\mathrm{DCAD} \times$ day length interaction.

Table 6. Milk fat, protein, and lactose content, and milk SCC of cows fed low or high DCAD diets and submitted to short (SD) and long days $(\mathrm{LD})$

\begin{tabular}{|c|c|c|c|c|c|c|c|c|}
\hline Item & \multicolumn{2}{|c|}{ DCAD $0^{1}$} & \multicolumn{2}{|c|}{ DCAD $400^{1}$} & $\mathrm{RMSE}^{1}$ & \multicolumn{3}{|c|}{$P$-value } \\
\hline Milk fat content, $\mathrm{g} / \mathrm{kg}$ & 34.9 & 33.5 & 37.3 & 34.2 & 1.73 & 0.087 & 0.014 & 0.288 \\
\hline Milk $\mathrm{CP}$ content, $\mathrm{g} / \mathrm{kg}$ & 31.0 & 30.1 & 31.2 & 29.7 & 1.03 & 0.730 & 0.001 & 0.402 \\
\hline Milk true protein content, $\mathrm{g} / \mathrm{kg}$ & 29.6 & 28.2 & 30.1 & 27.8 & 0.63 & 0.983 & $<0.001$ & 0.129 \\
\hline Milk urea content, $\mathrm{mg} / \mathrm{kg}$ & 293.1 & 283.6 & 295.5 & 245.0 & 37.57 & 0.297 & 0.020 & 0.151 \\
\hline Milk true protein yield, $\mathrm{g} / \mathrm{d}$ & 999 & 942 & 936 & 903 & 71.9 & 0.162 & 0.187 & 0.711 \\
\hline Milk lactose content, $\mathrm{g} / \mathrm{kg}$ & 46.3 & 45.9 & 46.7 & 46.7 & 0.59 & 0.049 & 0.452 & 0.452 \\
\hline Milk SCC $(\times 1,000 / \mathrm{mL})$ & 224 & 270 & 500 & 207 & 223.5 & 0.334 & 0.240 & 0.115 \\
\hline
\end{tabular}

${ }^{1} \mathrm{DCAD} 0$ and DCAD $400=$ dietary cation anion difference of 0 or $400 \mathrm{mEq} / \mathrm{kg}$ of DM; RMSE = root mean square prediction error; interaction $=\mathrm{DCAD} \times$ day length interaction.

Table 7. Calcium and phosphorous intake, excretion, and balance of cows fed low or high DCAD diets and submitted to short (SD) and long days $(\mathrm{LD})$

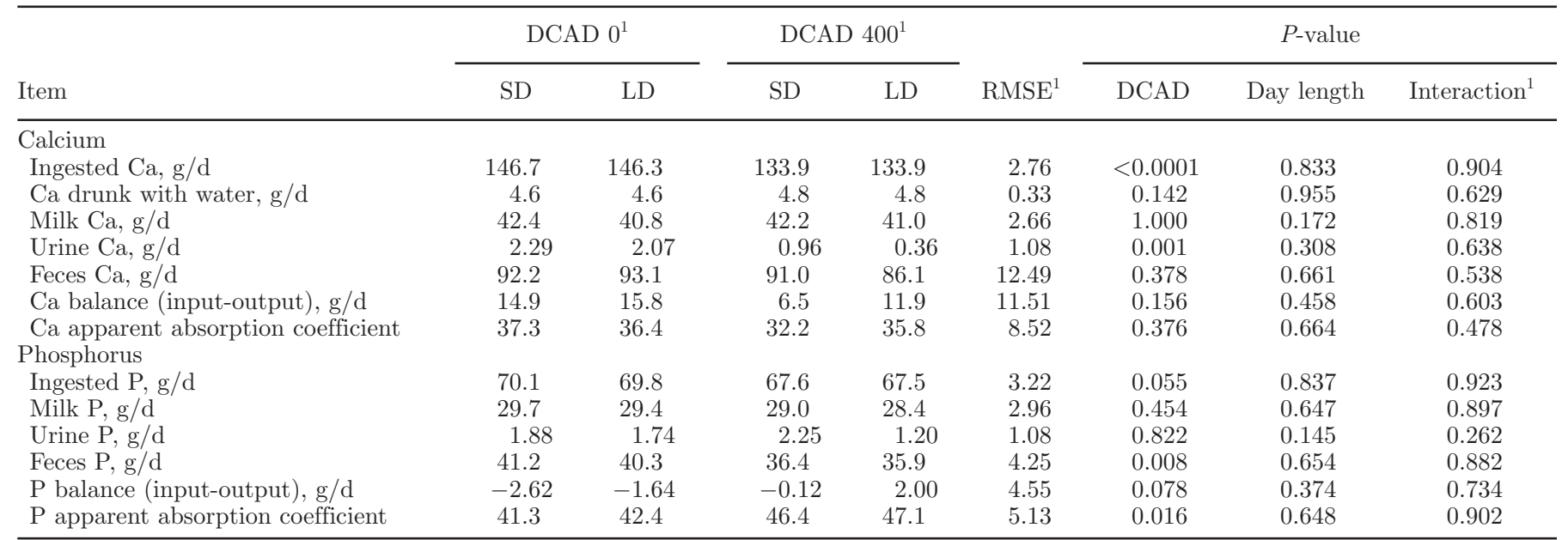

${ }^{1}$ DCAD 0 and DCAD $400=$ dietary cation anion difference of 0 or $400 \mathrm{mEq} / \mathrm{kg}$ of DM; RMSE = root mean square prediction error; interaction $=\mathrm{DCAD} \times$ day length interaction. 
cin concentrations ( 41.1 vs. $36 \mathrm{ng} / \mathrm{mL}, P<0.04)$. The DCAD did not affect plasma CTX concentrations.

\section{Day Length Effect}

Total DMI, milk yield and FCM, $\mathrm{NE}_{\mathrm{L}}$ and PDI supplies, absorbable $\mathrm{Ca}$ and $\mathrm{P}$ supplies, as well as $\mathrm{NE}_{\mathrm{L}}$ and PDI balances and absorbable $\mathrm{Ca}$ and $\mathrm{P}$ supply excess, were not affected by day length $(P>0.10$, Table 3$)$.

Long days clearly decreased evening milk melatonin content (5.1 vs. $14.2 \mathrm{pg} / \mathrm{mL}$ for LD compared with SD, $P<0.001$, Table 4). Day length did not affect morning milk melatonin content and plasma circulating levels of $25-\mathrm{OH}$ vitamin $\mathrm{D}(P>0.10)$. Day length also did not affect blood $\mathrm{pH}, \mathrm{HCO}_{3}{ }^{-}$content, $\mathrm{pCO}_{2}$, extracellular base excess, $\left[\mathrm{SID}^{+}\right]$, ionized $\mathrm{Ca}$ content, blood total $\mathrm{Ca}$ and $\mathrm{P}$ content, or urine $\mathrm{pH}(P>0.10)$. Plasma levels of $25-\mathrm{OH}$ vitamin $\mathrm{D}$ increased from $48.1 \mathrm{ng} / \mathrm{mL}$ at the end of the first period to $62.1 \mathrm{ng} / \mathrm{mL}$ at the end of the last period $(P<0.05)$.

Long days decreased milk total Ca content (1,231 vs. $1,265 \mathrm{mg} / \mathrm{kg}, P<0.001$, Table 5) and colloidal Ca content $(860$ vs. $894 \mathrm{mg} / \mathrm{kg}, P<0.002)$. Day length had no effect on soluble $\mathrm{Ca}$ and $\mathrm{Ca}$-to- $\mathrm{CN}$ ratio $(P>0.10)$ as well as on soluble, colloidal $\mathrm{P}$, and citrate contents. The LD also decreased milk fat content (33.9 vs. 36.1 $\mathrm{g} / \mathrm{kg}, P<0.02$, Table 6$)$, milk $\mathrm{CP}$ content (29.9 vs. $31.1 \mathrm{~g} / \mathrm{kg}, P<0.001)$, milk true protein content $(28.0$ vs $29.9 \mathrm{~g} / \mathrm{kg}, P<0.001)$, and milk CN content $(22.3$ vs. $22.9 \mathrm{~g} / \mathrm{kg}, P<0.005)$ and tended to decrease milk soluble protein content $(6.00$ vs. $6.35 \mathrm{~g} / \mathrm{kg}, P<0.06)$. Day length had no effect on milk lactose content.

During the $3 \mathrm{~d}$ of mineral balance measurement, day length had no effect on any flow of animal $\mathrm{Ca}$ and $\mathrm{P}$ balance $(P>0.10$, Table 7$)$. It also did not affect animal $\mathrm{Ca}$ and $\mathrm{P}$ balance, apparent $\mathrm{Ca}$ and $\mathrm{P}$ absorption coefficient, or amount of $\mathrm{Ca}$ and $\mathrm{P}$ absorbed in the digestive tract. The LD tended to increase morning and evening plasma osteocalcin concentrations (respectively
42.8 vs. $48.8 \mathrm{ng} / \mathrm{mL}, P=0.052$, and 36.3 vs. $40.8 \mathrm{ng} /$ $\mathrm{mL}, P=0.064$, Table 8 ), but day length had no effect on plasma CTX concentrations.

\section{DISCUSSION}

\section{Effect of DCAD on Blood pH and lonized Ca Content}

The purpose of this experiment was to test the hypothesis that the decrease in milk Ca content observed in spring in France could be linked to the high DCAD value of grazed herbage during this season. Indeed, Roche et al. (2000) showed that herbage DCAD can be particularly high in spring with values exceeding 400 $\mathrm{mEq} / \mathrm{kg}$ of $\mathrm{DM}$, which is much higher than the values observed for supplemented conserved forage (ApperBossard et al., 2006). In our experiment, the DCAD of $400 \mathrm{mEq} / \mathrm{kg}$ of DM, assumed to be representative of grazed herbage, was compared with a DCAD of $0 \mathrm{mEq} /$ $\mathrm{kg}$ of DM. The DCAD of $0 \mathrm{mEq} / \mathrm{kg}$ of DM can be considered as low even for a diet based on supplemented forage (Hu and Murphy, 2004) but has the advantage of increasing the compared DCAD gap between the treatments.

The effect of DCAD on blood acid-base parameters was expected. Given that the cows did not suffer any respiratory difficulties during the experiment, the increase in blood $\mathrm{pCO}_{2}$ is an initial indication that the cows offered the DCAD 400 diets incurred blood alkalinization of metabolic origin (Constable, 1999). This was confirmed by the slight increase in blood $\mathrm{pH}$, but also by the clear increase in blood extracellular base excess and urine $\mathrm{pH}$, the increase in blood $\mathrm{HCO}_{3}{ }^{-}$content and the increase in blood measured $\left[\mathrm{SID}^{+}\right.$] (Constable, 1999). All these parameters are suggestive of subacute metabolic alkalosis with partial respiratory compensation (Shapiro et al., 1992). On DCAD 400, the cows were even at the limit of the criteria retained to define strong ion (or metabolic) alkalosis, with a blood pH ex-

Table 8. Blood bio-markers of bone accretion-resorption of cows fed low or high DCAD diets and submitted to short (SD) and long days (LD)

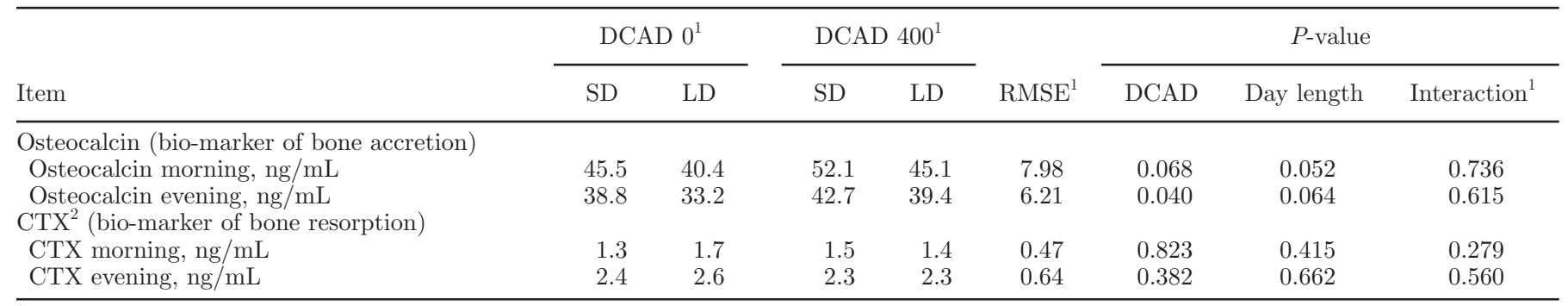

${ }^{1}$ DCAD 0 and DCAD $400=$ dietary cation anion difference of 0 or $400 \mathrm{mEq} / \mathrm{kg}$ of DM; RMSE = root mean square prediction error; interaction $=\mathrm{DCAD} \times$ day length interaction.

${ }^{2}$ Carboxy-terminal cross-linking telopeptide of type I collagen (CTX). 
ceeding 7.45, blood $\mathrm{HCO}_{3}{ }^{-}$content close to $32 \mathrm{mmol} / \mathrm{L}$, blood $\left[\mathrm{SID}^{+}\right.$] higher than $46 \mathrm{mEq} / \mathrm{L}$, and extracellular base excess close to $8 \mathrm{mEq} / \mathrm{L}$ (Constable, 1999).

In accordance with our hypothesis, the increase in blood $\mathrm{pH}$ we observed with DCAD 400 was associated with a significant decrease in blood ionized Ca concentration without any significant variation of total blood Ca concentration. Moore (1970) clearly illustrated, in human blood in vitro, a linear or slightly sigmoid decrease in blood ionized Ca concentration with increasing $\mathrm{pH}$, resulting from competition between $\mathrm{Ca}^{2+}$ and $\mathrm{H}^{+}$for negative sites on serum proteins. This effect of $\mathrm{pH}$ was virtually instantaneous and was completely reversible. This effect was also clearly observed, to the same extent as ours, in the meta-analysis of Charbonneau et al. (2006) and in the study of Wang and Beede (1992) conducted on dairy cows.

\section{High DCAD Increased Milk Ca}

Even though DCAD 400 reduced the blood ionized Ca concentration in cows, it increased the milk Ca concentration, which contradicted our hypothesis. These results suggest that the availability of blood $\mathrm{Ca}$ is not determinant for Ca uptake by the mammary gland, at least under our experimental conditions, with nonlimiting $\mathrm{Ca}$ intake compared with cows daily allowance.

In our experiment, blood alkalization with DCAD 400 had an expected effect on Ca urine excretion, which decreased (Wang and Beede, 1992; Bushinsky, 2010), and bone accretion, which increased as indicated by the increased level of blood osteocalcin (Bushinsky and Frick, 2000). These effects are the result of complementary mechanisms described for humans. First, as stated above, a higher systemic $\mathrm{pH}$ will decrease the proportion of ionized $\mathrm{Ca}$ that is also filterable at the glomerular level and increase overall renal tubule fractional reabsorption of $\mathrm{Ca}$ through a direct effect of increased bicarbonate on renal tubular Ca reabsorption (Bushinsky, 2010). At the same time, a high $\mathrm{pH}$ has been shown to increase Ca influx into cultured bone due to direct physiochemical $\mathrm{Ca}$ accretion, but also to a cell mediating mechanism with inhibition of osteoclastic activity and activation of osteoblastic activity (Bushinsky and Frick, 2000). These latter results, mainly obtained on cultured bones, are consistent with our observation that DCAD 400 treatment increases osteocalcin blood content, which is an indicator of bone accretion, even though no effect of DCAD on CTX and bone resorption could be observed.

The reasons for which blood alkalinization led to an increase in $\mathrm{Ca}$ milk content are less obvious. At this stage, it cannot be determined whether chronic change in the acid-base status of the animals generated in this experiment was linked to the systemic regulation of blood Ca content of lactating females that could have simultaneously affected $\mathrm{Ca}$ excretion in urine, bone accretion, and $\mathrm{Ca}$ secretion in milk, or to a local change of calcium excretion in milk. It is interesting to highlight that, when DCAD increased or when day length decreased, milk Ca content increased simultaneously with bone accretion. In lactating mammals, and more specifically in goats and mice, it has been shown that PTH-related protein (PTHrP) is responsible of an increased Ca secretion in milk (Barlet et al., 1992; VanHouten et al., 2003). At the same time, PTHrP is also a key hormone of blood Ca regulation in lactating mammals that increases bone resorption and renal tubular reabsorption during lactation (Kovacs, 2005). This hormone could be a missing link between the effects of our treatments on milk Ca and bone accretion. However, this hypothesis could not be confirmed given that milk contents of PTHrP were not analyzed and no data are available concerning the effect of systemic acidosis or alkalosis on PTHrP secretion.

\section{Effect of Day Length on Melatonin and 25-OH Vitamin D Synthesis}

The decrease in milk melatonin content in the evening with LD is a clear indication that LD decreased melatonin secretion by the pineal gland. Melatonin is a hormone produced and secreted by the pineal gland and whose secretion is inhibited when photo-perception occurs at the retina in conditions of light (Dahl et al., 2000). Consequently, plasma concentrations of melatonin are low during light periods, increasing rapidly during dark periods (Dahl et al., 2000). It has been shown in dairy cows that milk melatonin content, measured during repeated milking throughout the day, is correlated with plasma melatonin (Castro et al., 2011). It was assumed in the present experiment that milk melatonin content would give an integrated view of changes in plasma melatonin levels during a few hours through milk accumulation in the cistern of cows' udders. The lower melatonin content of milk with LD at the evening milking was consistent with the fact that cows receiving LD treatments were continuously exposed to light during the hours preceding milking, whereas cows receiving SD treatments were subjected to $1.75 \mathrm{~h}$ of darkness before milking. The absence of day length effect on morning milk melatonin content may be explained by the accumulation of melatonin-containing cistern milk during the night for both treatments, even though cows receiving $\mathrm{LD}$ treatment were exposed to $1.75 \mathrm{~h}$ of light before milking, contrary to the cows subjected to SD treatment. 
The absence of day length effect on plasma $25-\mathrm{OH}$ vitamin D shows that the day length effects we observed on milk Ca content were more likely linked to a photoperiod rather than to a UV radiation effect. The long duration of the daily exposure of cows to UVB in both $\mathrm{SD}$ and LD treatments, and a possible loss of vitamin $\mathrm{D}$ in milk, before its conversion to $25-\mathrm{OH}$ vitamin $\mathrm{D}$, could be 2 reasons explaining the lack of effect of day length on plasma $25-\mathrm{OH}$ vitamin $\mathrm{D}$ in this experiment.

Vitamin D is synthetized in the skin, in the presence of sunlight, from 7-dehydrocholesterol through previtamin D (MacLaughlin et al., 1982). The conversion rate of previtamin $\mathrm{D}$ to vitamin $\mathrm{D}$ is almost negligible if sunlight does not provide UVB and is maximal when light wavelength is between 295 and $300 \mathrm{~nm}$ (MacLaughlin et al., 1982). In our experiment, the provided light (Osram Ultra-vitalux bulbs) was conceived to emit a significant amount of wavelengths between 295 and $300 \mathrm{~nm}$ and likely allowed a significant conversion of previtamin D to vitamin $\mathrm{D}$. The fact that plasma $25-\mathrm{OH}$ vitamin $\mathrm{D}$ of cows increased from the first to the last period is coherent with this assumption. Given the nature of the provided light, it is likely that the light exposure durations of cows of both SD and LD treatments were long enough to obtain synthesis of a high amount of vitamin $\mathrm{D}$. This is consistent with the high levels of plasma 25-OH vitamin $\mathrm{D}$ we observed compared with the range of values reported as normal in dairy cows (Horst et al., 1994). It cannot be excluded either that the light exposure durations of cows of both SD and LD treatments were long enough to create a saturation of the capacity of cutaneous vitamin D synthesis. Indeed, recommended duration of sunlight exposure for humans to obtain a sufficient amount of vitamin $\mathrm{D}$ synthesis does not exceed $40 \mathrm{~min} / \mathrm{d}$ with sunlight providing a significant amount of UVB (Webb, 2006). It has been showed that the duration of sunlight exposure is an important factor of regulation of cutaneous vitamin $\mathrm{D}$ production (Webb et al., 1989) and that $3 \mathrm{~h}$ exposure of human skin samples to sunlight providing UVB can degrade as much as $95 \%$ of the vitamin D initially present in the sample (Webb et al., 1989). Even though the duration of UVB exposure to obtain a similar increased of plasma 25-OH vitamin D may be higher in cows compared with humans (Hymøller and Jensen, 2012), the high plasma $25-\mathrm{OH}$ vitamin $\mathrm{D}$ content we obtained in our experiment for both day lengths likely indicates that either the saturation of capacity cutaneous vitamin D synthesis was reached for both day lengths or that an enhanced catabolism of 25-OH vitamin D occurred in the intestine and kidney for LD (Horst et al., 1994).

Circulating level of 25-OH vitamin D arises from the hydroxylation in the liver of vitamin $\mathrm{D}$ synthetized by the skin and is mainly used as an indicator of the animal's vitamin D status (Hymøller et al., 2009). However, before being hydroxylated in the liver, circulating vitamin $\mathrm{D}$ can be either excreted in milk or, at least theoretically, stored in tissue, which can also have minimized the day length effect on the circulating level of $25-\mathrm{OH}$ vitamin $\mathrm{D}$ in our experiment. It has been shown that vitamin D passes easily into milk, whereas the transfer of $25-\mathrm{OH}$ vitamin D into milk is lower (McDermott et al., 1985, Kasalová et al., 2015). If we assume that transfer of vitamin D into milk could have been more rapid than liver hydroxylation, it cannot be excluded that a higher part of vitamin D passes into milk when more vitamin $\mathrm{D}$ is synthetized (i.e., on LD treatment). Milk vitamin D content was not analyzed in our experiment, but the results of Jakobsen et al. (2015) illustrated a clear effect of UVB exposure on milk vitamin D contents. Theoretically, circulating vitamin $\mathrm{D}$ could also be stored in tissue to be hydroxylized by the liver. However, Hymøller et al. (2009) observed in steers than storage of vitamin D synthetized by the skin is likely very low and Jones (2008) stated that this phenomena should be more limited if vitamin $\mathrm{D}$ is synthetized by the skin rather than ingested as a supplement given the different nature of the plasma vitamin $\mathrm{D}$ transport for both origins of vitamin D (i.e., protein carriers vs. chylomicrons).

\section{Milk Ca Content and Bone Accretion Decreased with Long Days}

The decreased milk Ca content with LD in our experiment was associated with decreased milk CN content, which should be a driving force for lower Ca content. Indeed, about two-thirds of milk $\mathrm{Ca}$ is associated with $\mathrm{CN}$ micelles and micellar Ca phosphates are responsible for the structure and stability of CN micelles (Gaucheron, 2005). A good correlation is generally observed between milk Ca and protein content (Bijl et al., 2013) even though, in the present experiment, the effect of DCAD on milk Ca was not accompanied by an increase in $\mathrm{CN}$ secretion.

Our results suggest that photoperiod could affect milk Ca content, but this photoperiod effect would only partly explain the decrease of milk Ca content observed during spring in France (Hurtaud et al., 2011, 2014). Indeed milk Ca content decreased by only $35 \mathrm{mg} / \mathrm{kg}$ between SD and LD, whereas Hurtaud et al. (2014) observed minimal decreased of milk Ca of about $80 \mathrm{mg} /$ $\mathrm{kg}$ between spring and winter. Moreover, our results may not totally be representative to the photoperiodic effect observed in the field. In most experiments testing the effects of photoperiod on lactating cows, a clear increase in milk production was observed with LD, with no effect on milk composition, with the exception of a 
few studies showing a slight decrease in milk fat content (Dahl et al., 2000). The short experimental periods of our experiment could explain these discrepancies. Phillips and Schofield (1989) also underlined such a discrepancy between a continuous experiment with light treatments longer than 2 mo and an experiment consisting of a change-over design with four 3 -wk periods with contrasting light schedules. With the short period experiments, these authors observed a negative effect of LD on milk protein content and no effect of day length on milk production, at least when light intensity was high.

The lower plasma osteocalcin content with $\mathrm{LD}$ in the present experiment was highly consistent with the large body of evidence accumulated in several species indicating that melatonin is able to reduce bone loss (Cardinali et al., 2003; Egermann et al., 2011; Taylor et al., 2013). It is interesting to note that the negative effect of LD on bone accretion was also associated with a negative effect on milk Ca content, reinforcing the notion of a link between both parameters already observed for DCAD.

\section{CONCLUSIONS}

We can conclude that the high DCAD of grass is not the reason for the decrease in cow Ca milk content when cows are grazing because, contrary to our hypothesis, the Ca content of milk increases with high DCAD. The decrease of milk Ca content observed during May and June in France could be partly explained by a photoperiod effect, even though the amplitude of the day light effect on milk Ca content in the present experiment was low compared with the amplitude of the Ca decrease observed by Hurtaud et al. (2011, 2014) in spring. The increase of milk Ca content with high DCAD and SD treatments was associated with increased bone accretion, but the experiment did not allow us to determine whether a common mechanism could link both responses with both high DCAD and LD treatments.

\section{ACKNOWLEDGMENTS}

The authors are grateful to the staff of the experimental farm of Méjussaume (INRA, Le Rheu, France), in particular to all the members of the physiology team for carrying out this experiment, and to the staff of the UMR 1348 laboratory (INRA Agrocampus Ouest, Saint Gilles, France), in particular to T. Le Mouël, N. Huchet, R. Comte, P. Debournoux, and Y. JaguelinPeyraud for the laboratory analyses. The authors are also very grateful to Philippe Chemineau for his valuable advice and Didier Chesneau (INRA, Tours,
France) for milk melatonin analyses. This study was funded by the department PHASE (Physiologie Animale et Système d'Elevage) of the INRA [Paris, France, "Crédit Incitatif" Call, Calcium Project, 2011-2012].

\section{REFERENCES}

AFNOR. 1997. Aliments des animaux-Dosage de l'azote-Méthode par combustion (DUMAS)-NF V18-120. AFNOR Editions, SaintDenis La Plaine, France.

Apper-Bossard, E., J. L. Peyraud, P. Faverdin, and F. Meschy. 2006. Changing dietary cation-anion difference for dairy cows fed with two contrasting levels of concentrate in diets. J. Dairy Sci. 89:749760.

Barlet, J.-P., C. Champredon, V. Coxam, M. J. Davicco, and J. C. Tressol. 1992. Parathyroid hormone-related peptide might stimulate calcium secretion into the milk of goats. J. Endocrinol. 132:353-359.

Bijl, E., H. J. F. van Valenberg, T. Huppertz, and A. C. M. van Hooijdonk. 2013. Protein, casein, and micellar salts in milk: Current content and historical perspectives. J. Dairy Sci. 96:5455-5464.

Bushinsky, D. A. 2010. Contribution of intestine, bone, kidney, and dialysis to extracellular fluid calcium content. Clin. J. Am. Soc. Nephrol. 5(Suppl. 1):S12-S22.

Bushinsky, D. A., and K. K. Frick. 2000. The effects of acid on bone. Curr. Opin. Nephrol. Hypertens. 9:369-379.

Cardinali, D. P., M. G. Ladizesky, V. Boggio, R. A. Cutrera, and C. Mautalen. 2003. Melatonin effects on bone: Experimental facts and clinical perspectives. J. Pineal Res. 34:81-87.

Caroli, A., A. Poli, D. Ricotta, G. Banfi, and D. Cocchi. 2011. Invited review: Dairy intake and bone health: A viewpoint from the state of the art. J. Dairy Sci. 94:5249-5262.

Castro, N., M. Spengler, V. Lollivier, O. Wellnitz, H. H. D. Meyer, and R. M. Bruckmaier. 2011. Diurnal pattern of melatonin in blood and milk of dairy cows. Milchwissenschaft 66:352-353.

Charbonneau, E., D. Pellerin, and G. R. Oetzel. 2006. Impact of lowering dietary cation-anion difference in nonlactating dairy cows: A meta-analysis. J. Dairy Sci. 89:537-548.

Chesneau, D., J.-P. Ravault, and J. Pelletier. 1994. Etude de la mélatonine dans le lait de la brebis allaitante. Pages 75-79 in CompteRendu Journée d'information CRITT-ISIS de Tours du 7 juin 1994. Edition CRITT-ISIS, Nouzilly, France.

Constable, P. D. 1999. Clinical assessment of acid-base status. Strong ion difference theory. Vet. Clin. North Am. Food Anim. Pract. 15:447-471.

Dahl, G. E., B. A. Buchanan, and H. A. Tucker. 2000. Photoperiodic effects on dairy cattle: A review. J. Dairy Sci. 83:885-893.

Dahl, G. E., and D. Petitclerc. 2003. Management of photoperiod in the dairy herd for improved production and health. J. Anim. Sci. 81(Suppl. 3):11-17.

Egermann, M., C. Gerhardt, A. Barth, G. Maestroni, E. Schneider, and M. Alini. 2011. Pinealectomy affects bone mineral density and structure - An experimental study in sheep. BMC Musculoskelet. Disord. 12:271.

Gaucheron, F. 2005. The minerals of milk. Reprod. Nutr. Dev. 45:473483.

Guéguen, L., and M. Journet. 1961. Les variations de la composition minérale du lait de vache. Ann. Biol. Anim. Biochem. Biophys. $1: 305-310$.

Horst, R. L., J. P. Goff, and T. A. Reinhardt. 1994. Calcium and vitamin D metabolism in the dairy cow. J. Dairy Sci. 77:1936-1951.

Hu, W., and M. R. Murphy. 2004. Dietary cation-anion difference effects on performance and acid-base status of lactating dairy cows: A meta-analysis. J. Dairy Sci. 87:2222-2229.

Hurtaud, C., M. Dutreuil, M. Coppa, C. Agabriel, and B. Martin. 2014. Characterization of milk from feeding systems based on herbage or corn silage with or without flaxseed and authentication through fatty acid profile. Dairy Sci. Technol. 94:103-123. 
Hurtaud, C., M. Johan, S. Laurent, Y. Gallard, and L. Delaby. 2011. Evolution of milk calcium content during the year. Pages 37-38 in Proc. 10th Int. Meeting on Mountain Cheese. University of Turin, Italy.

Hurtaud, C., S. Lemosquet, and H. Rulquin. 2000. Effects of graded duodenal infusions of glucose on yield and composition of milk from dairy cows. 2. Diets based on grass silage. J. Dairy Sci. 83:2952-2962.

Hymøller, L., and S. K. Jensen. 2010. Vitamin D3 synthesis in the entire skin surface of dairy cows despite hair coverage. J. Dairy Sci. 93:2025-2029.

Hymøller, L., and S. K. Jensen. 2012. 25-Hydroxycholecalciferol status in plasma is linearly correlated to daily summer pasture time in cattle at $56^{\circ} \mathrm{N}$. Br. J. Nutr. 108:666-671.

Hymøller, L., S. K. Jensen, H. Lindqvist, B. Johansson, M. O. Nielsen, and E. Nadeau. 2009. Supplementing dairy steers and organically managed dairy cows with synthetic vitamin D3 is unnecessary at pasture during exposure to summer sunlight. J. Dairy Res. 76:372378.

INRA. 2007. Alimentation des Bovins Ovins Caprins: Besoins des Animaux et Tables des Aliments. Editions QUAE, Versailles, France.

Jakobsen, J., S. K. Jensen, L. Hymøller, E. W. Andersen, P. Kaas, A. Burild, and R. B. Jäpelt. 2015. Short communication: Artificial ultraviolet B light exposure increases vitamin D levels in cow plasma and milk. J. Dairy Sci. 98:6492-6498.

Jones, G. 2008. Pharmacokinetics of vitamin D toxicity. Am. J. Clin. Nutr. 88:582S-586S.

Jones, G., S. A. Strugnell, and H. F. DeLuca. 1998. Current understanding of the molecular actions of vitamin D. Physiol. Rev. 78:1193-1231.

Kasalová, E., J. Aufartová, L. K. Krčmová, D. Solichová, and P. Solich. 2015. Recent trends in the analysis of vitamin D and its metabolites in milk-A review. Food Chem. 171:177-190.

Kovacs, C. S. 2005. Calcium and bone metabolism during pregnancy and lactation. J. Mammary Gland Biol. Neoplasia 10:105-118.

Ladizesky, M. G., V. Boggio, R. A. Cutrera, N. Mondelo, S. Mastaglia, J. Somoza, and D. P. Cardinali. 2006. Melatonin effect on bone metabolism in rats treated with methylprednisolone. J. Pineal Res. 40:297-304.

MacLaughlin, J. A., R. Anderson, and M. Holick. 1982. Spectral character of sunlight modulates photosynthesis of previtamin D3 and its photoisomers in human skin. Science 216:1001-1003.

Malacarne, M., P. Franceschi, P. Formaggioni, S. Sandri, P. Mariani, and A. Summer. 2014. Influence of micellar calcium and phosphorus on rennet coagulation properties of cows milk. J. Dairy Res. 81:129-136.

McDermott, C. M., D. C. Beitz, E. T. Littledike, and R. L. Horst. 1985. Effects of dietary vitamin D3 on concentrations of vitamin
D and its metabolites in blood plasma and milk of dairy cows. J. Dairy Sci. 68:1959-1967.

Meschy, F. 2010. Nutrition Minérale Des Ruminants. Editions Quae, Versailles, France.

Moore, E. W. 1970. Ionized calcium in normal serum, ultrafiltrates, and whole blood determined by ion-exchange electrodes. J. Clin. Invest. 49:318-334.

NRC. 2001. Nutrient Requirements of Dairy Cattle. National Academic Press, Washington, DC.

Phillips, C. J. C., and S. A. Schofield. 1989. The effect of supplementary light on the production and behaviour of dairy cows. Anim. Sci. 48:293-303

Pien, J. 1969. Dosage du phosphore dans le lait. Lait 49:175-188.

Roche, J., D. Dalley, P. Moate, C. Grainger, M. Hannah, F. O'Mara, and M. Rath. 2000. Variations in the dietary cation-anion difference and the acid- base balance of dairy cows on a pasture-based diet in south-eastern Australia. Grass Forage Sci. 55:26-36.

Shapiro, B. A., R. A. Harrison, R. D. Cane, and R. Templin. 1992 Gaz du sang-Applications cliniques. Editions Frison-Roche, Paris, France.

Taylor, A. C., M. Horvat-Gordon, A. Moore, and P. A. Bartell. 2013. The effects of melatonin on the physical properties of bones and egg shells in the laying hen. PLoS ONE 8:e55663.

van Driel, M., M. Koedam, C. J. Buurman, M. Roelse, F. Weyts, H Chiba, A. G. Uitterlinden, H. A. P. Pols, and J. P. T. M. van

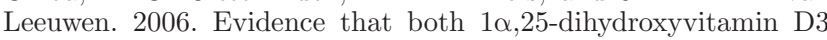
and 24-hydroxylated D3 enhance human osteoblast differentiation and mineralization. J. Cell. Biochem. 99:922-935.

VanHouten, J. N., P. Dann, A. F. Stewart, C. J. Watson, M. Pollak, A. C. Karaplis, and J. J. Wysolmerski. 2003. Mammary-specific deletion of parathyroid hormone-related protein preserves bone mass during lactation. J. Clin. Invest. 112:1429-1436.

van Hulzen, K. J. E., R. C. Sprong, R. van der Meer, and J. A. M. van Arendonk. 2009. Genetic and nongenetic variation in concentration of selenium, calcium, potassium, zinc, magnesium, and phosphorus in milk of Dutch Holstein-Friesian cows. J. Dairy Sci. 92:5754-5759

Van Soest, P. J., J. B. Robertson, and B. A. Lewis. 1991. Methods for dietary fiber, neutral detergent fiber and nonstarch polysaccharides in relation to animal nutrition. J. Dairy Sci. 74:3583-3597.

Wang, C., and D. K. Beede. 1992. Effects of ammonium chloride and sulfate on acid-base status and calcium metabolism of dry Jersey cows. J. Dairy Sci. 75:820-828.

Webb, A. R. 2006. Who, what, where and when-Influences on cutaneous vitamin D synthesis. Prog. Biophys. Mol. Biol. 92:17-25.

Webb, A. R., B. R. DeCosta, and M. F. Holick. 1989. Sunlight regulates the cutaneous production of vitamin $\mathrm{D}_{3}$ by causing its photodegradation. J. Clin. Endocrinol. Metab. 68:882-887. 